\title{
Pembuatan Pasta Gigi Katekin Teh Hijau dan Uji Daya Hambat terhadap Bakteri Streptococcus Mutans dan Lactobascillus Ascidopillus
}

\author{
Fajriani* dan Sartini Djide** \\ *Departemen IImu Kedokteran Gigi Anak, Fakultas Kedokteran Gigi, Universitas Hasanuddin, Makassar, Sulawesi Selatan, Indonesia \\ **Departemen IImu Farmasi, Fakultas Matematika dan IImu Pengetahuan Alam, Universitas Hasanuddin, Makassar, Sulawesi \\ Selatan, Indonesia \\ *JI Raya Pendidikan blok B4/14 Makassar, Sulawesi Selatan, Indonesia; e-mail: fajriani_fkg@yahoo.com
}

\begin{abstract}
ABSTRAK
Pembuatan pasta gigi ini dilatar belakangi oleh keinginan peneliti agar memudahkan masyarakat menggunakan bahan alami katekin teh hijau yang hasilnya langsung di uji efektifitasnya terhadap daya hambat bakteri kariogenik. Penelitian ini bertujuan untuk melakukan pembuatan prodak pasta gigi katekin teh hijau dengan formula yang sesuai dengan hasil uji dan melakukan pengujian daya hambat pasta gigi katekin teh hijau terhadap bakteri streptococcus mutans dan lactobacillus acidophilus. Pembuatan pasta gigi katekin teh hijau didahului dengan pembuatan ekstrak katekin dan uji konsentrasi hambat minimal (KHM) dan uji konsentrasi bunuh minimal (KBH) menggunakan metode dilusi cair. Peracikan formula dan pembuatan pasta gigi katekin teh hijau dilakukan sesuai hasil uji KHM (MIC). Pasta gigi katekin teh hijau ini dilakukan pengukuran kadar total flavonoid dan total polifenol, selanjutnya pengukuran uji daya hambat pasta gigi katekin teh hijau dilakukan dengan metode difusi menggunakan well (sumuran) sebagai reservoar sampel uji terhadap bakteri streptococus mutans dan lactobacilus acidophilus. Hasil diperoleh prodak pasta gigi katekin teh hijau dengan kandungan kadar flavonoid $77 \%$ dan kadar polifenol $41 \%$, sedangkan hasil uji diameter hambatan pasta gigi katekin teh hijau terhadap bakteri streptococcus mutans 17,2 mm dan bakteri lactobacillus acidophilus 19,6 mm. Hasil ini menunjukkan bahwa prodak katekin teh hijau ini sangat efektif digunakan sehari-hari sebagai perawatan gigi dan juga sebagai antibakteri kariogenik.
\end{abstract}

Maj Ked Gi Ind. Juni 2015; 1(1): hal 27-31

Kata kunci: Pasta gigi katekin teh hijau, uji daya hambat, streptococcus mutas dan lactobaccilus acidophil

\begin{abstract}
Making Green Tea Catechin Toothpaste and Inhibition Test Against Streptococcus Mutans And Acidophilus Lactobaccilus. The manufacture of this toothpaste is motivated by the desire of researchers to facilitate the public to use natural ingredients of green tea catechins whose result effectiveness against cariogenic bacteria was directly tested inhibition. This study is to find the right formula composition for greentea catechins toothpaste based on the result of the inhibition properties of greentea cathecins against tostreptococcus mutans dan lactobacillus acidophilus. The manufacture of greentea catechins toothpaste was after making catechins extracts and testing minimal inhibition concentration (MIC) and minimal bactericidal concentration (MBC) using liquid dilution method. The toothpaste was then made according to the result of MIC. The toothpaste's flavonoid and polyphenol total contain was measured; then the inhibition property of the toothpaste to was measured using diffusion method with wells as the sample reservoar for streptococus mutans dan lactobacilus acidophilus. It is found that the toothpaste contains $77 \%$ flavonoid and $41 \%$ polyphenol, and the diameter of the inhibition property of green tea catechyn is $17.2 \mathrm{~mm}$ for streptococus mutans and $19.6 \mathrm{~mm}$ for lactobacilus acidophilus. This result shows that greentea catechyn toothpaste is very effective for daily oral care which is antibacterial.

Maj Ked Gi Ind. Juni 2015; 1(1): hal 27-31
\end{abstract}

Keywords: greentea catechyn toothpaste, inhibition test, streptococus mutans, lactobacilus acidophilus

\section{PENDAHULUAN}

Kesehatan gigi dan mulut mengalami peningkatan setiap tahunnya akan tetapi prevalensi terjadinya karies gigi pada anak tetap merupakan masalah klinik yang signifikan. Hasil Survei Kesehatan Rumah Tangga (SKRT) tahun 2004, tingkat karies di Indonesia adalah 90,05\% dari penduduk Indonesia. Sampai saat ini, karies gigi masih menjadi masalah utama dalam bidang kedokteran gigi dan menjadi salah satu penyakit infeksi yang paling umum pada anak. Menurut Riset Kesehatan Dasar (RISKESDAS) pada tahun 2007 yang dikutip oleh Darwita, prevalensi masalah kesehatan gigi dan mulut pada murid sekolah dasar mencapai $72,1 \%$. $^{1,2,3,4}$

Salah satu mikroba patogen penyebab karies yang banyak ditemukan dalam biofilm kariogenik atau plak adalah Streptococcus mutans. Telah banyak penelitian yang membuktikan adanya hubungan yang erat antara jumlah koloni bakteri 
Streptococcus mutans pada saliva dengan prevalensi karies gigi. Anak-anak dengan tingkat karies tinggi juga mengalami peningkatan jumlah koloni Streptococcus mutans. ${ }^{1,5,6,7}$

Penelitian yang pernah dilakukan terdahulu ditemukan tanaman herbal yang memiliki potensi besar sebagai obat pencegah penyakit gigi dan mulut, yaitu teh hijau. Teh hijau dapat digunakan sebagai obat kumur untuk menghambat pembentukan plak serta mencegah karies gigi, penyakit periodontal, halitosis dan kanker mulut. Selain itu, teh hijau juga dapat mencegah penyakit kardiovaskular, stroke, obesitas dan kanker. ${ }^{6,7.8}$

Komponen bioaktif dari teh hijau mampu mempengaruhi proses terjadinya karies gigi dengan menghambat proliferasi, produksi asam, metabolisme, dan aktivitas enzim glukosiltransferase (GTF) dari Streptococcus mutans dan plak. Penelitian Signoretto yang dikutip oleh Tehrani menunjukkan bahwa konsumsi teh hijau dapat menghambat deposisi plak dan mengurangi tingkat koloni Streptococcus mutans dan Lactobacillus pada plak dan saliva. Menurut Cao Jin yang dikutip oleh Wijaya, katekin dengan konsentrasi $0,125 \%$ $1 \%$ menunjukkan penurunan jumlah bakteri, pembentukan plak dan jumlah total protein bakteri dan extracellular glucan.9,10,11,12 Penelitian ini bertujuan untuk membuat prodak pasta gigi katekin teh hijau yang lebih efektif digunakan langsung pada masyarakat. Penelitian telah disetujui oleh komite etik no: 01740/H4.8.4.5.31/pp36.KOMETIK/2014.

\section{METODE PENELITIAN}

Pembuatan pasta gigi katekin teh hijau menggunakan teh hijau merk kepala janggot yang umum di konsumsi di Indonesia dan di beli di toko lokal kota Makassar. Proses ekstraksi teh hijau: dilakukan dengan bantuan jasa Pabrik Royal Medica Pharmalab Makassar. Sampel teh hijau 2,2 $\mathrm{kg}$ diserbukkan dan diayak dengan ayakan no. 60. Proses ekstraksi dilakukan dengan pelarut air dengan perbandingan 1:10 (air 22 L). Ekstraksi dilakukan selama 2 jam pada suhu $50^{\circ} \mathrm{C}$. Hasil ekstraksi kemudian dievaporasi dengan freezer drier selama 24 jam dengan suhu $-60^{\circ} \mathrm{C} .{ }^{11}$

Penentuan kadar hambat minimal ekstrak teh hijau dilakukan dengan metode dilusi cair yaitu dimulai dengan pembuatan larutan stok ekstrak teh hijau 4\% b/v, kemudian $4 \mathrm{~g}$ ekstrak didispersikan dalam air suling hingga $100 \mathrm{~mL}$. Media nutrien broth (NB) steril disiapkan dalam 20 tabung reaksi berukuran $5 \mathrm{~mL}$. Sementara itu disiapkan suspensi bakteri uji Lactobacillus acidophilus dan Streptococcus mutans. Sampel uji dilakukan pengenceran bertingkat hingga konsentrasi dalam tabung reaksi berisi media NB masing-masing $2 \%$, $1 \%, 0,5 \%, 0,25 \%$. Masing-masing tabung reaksi tersebut diinokulasi 1 ose bakteri uji dan diinkubasi selama 24 jam suhu $37^{\circ} \mathrm{C}$ kemudian diamati perubahan kekeruhan yang terjadi..$^{11.12}$

Pembuatan pasta gigi katekin teh hijau di awali dengan aiir suling $25 \mathrm{ml}$ dipanaskan hingga mendidih, dilarutkan metilparaben dan sakarin. Suhu sekitar $70^{\circ} \mathrm{C}$ didispersikan CMC (Carboxy Methyl Cellulose) hingga terbentuk gel, kemudian ekstrak teh hijau digerus dilumpang bersama sodium lauril sulfat lalu ditambahkan berturut-turut gliserin, sorbitol, dan gel CMC, digerus hingga terbentuk pasta yang homogen. ${ }^{11}$

Uji daya hambat pasta gigi ekstrak teh hijau dilakukan dengan metode difusi menggunakan well (sumuran) sebagai reservoar sampel uji. Dimulai dengan pasta gigi diencerkan 1:1 dengan air suling steril, sebanyak 100 ul sampel dimasukkan ke dalam media MHA steril yang telah diinokulasi dengan bakteri uji (S.mutans \& L.acidophilus ) 10 ul. Kemudian inkubasi dilakukan selama 24 jam suhu $37^{\circ} \mathrm{C} .{ }^{12}$

\section{HASIL PENELITIAN}

Ekstrak kering teh hijau merk kepala janggot, berbentuk serbuk halus $178 \mathrm{~g}$. Rendamen yg diperoleh: $178 \mathrm{~g} / 2200 \mathrm{~g} \times 100 \%=8,1 \%$.

Diperoleh hasil terlihat pada Tabel 1 , nilai konsentrasi hambat minimal (KHM) ekstrak teh hijau pada bakteri streptococcus mutans $0,5 \%$ dan KHM ekstrak teh hijau untuk bakteri lactobacillus acidophilus juga sama yaitu $0,5 \%$. Prosedur formulasi pembuatan pasta gigi katekin teh hijau dibuat sesuai standar dan konsentrasi katekin berdasarkan pedoman uji konsentrasi hambat minimal yang terlebih dahulu dilakukan. Hasil seperti yang terlihat pada Gambar 1 dalam tube dan pada Gambar 2 dalam pot. 
Tabel 1. Pertumbuhan bakteri uji setelah inkubasi 24 jam

\begin{tabular}{llllll}
\hline Bakteri uji & \multicolumn{7}{l}{ Konsentrasi Sampel Uji (\%) } & & \\
\hline & 2 & 1 & 0,5 & 0,25 & 0,125 \\
Streptococcus mutans & - & - & - & + & + \\
Lactobacillus acidophilus & - & - & - & + & + \\
\hline
\end{tabular}

Keterangan: replikasi dua kali: Tanda $(-)=$ tidak ada pertumbuhan bakteri; tanda $(+)=$ ada pertumbuhan bakteri

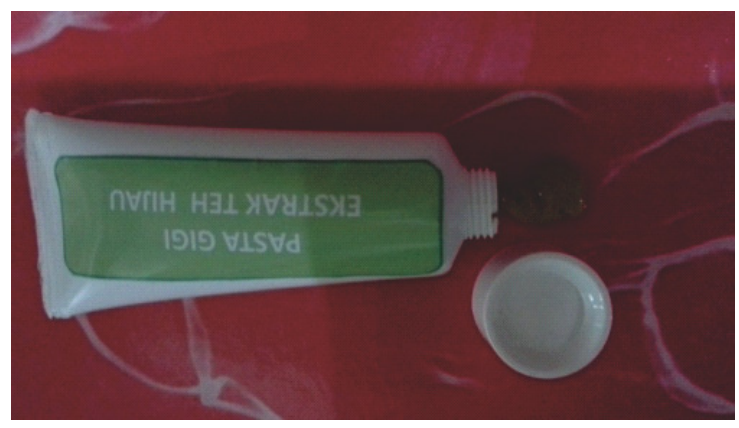

Gambar 1. pasta gigi katekin teh hijau dalam kemasan tube



Gambar 2. Pasta gigi katekin teh dalam pot

Tabel 2. Pengukuran kadar total flavonoid dan total polifenol

\begin{tabular}{lllllll}
\hline Sampel & Jenis Uji & $\begin{array}{l}\text { Panjang } \\
\text { gelombang }(\mathrm{nm})\end{array}$ & Pembanding & $\begin{array}{l}\text { Konsentrasi } \\
(\mathrm{ppm})\end{array}$ & Absorban & Kadar \\
\hline D1 (ekstrak & Total flavonoid & 281 & Katekin & 30 & 0,33233 & 0,77807 \\
teh hijau) & Total fenolik & 641,5 & As.gallat & 30 & 0,342 & 0,41063 \\
\hline
\end{tabular}

Hasil pengukuran kadar total flavonoid pasta gigi katekin teh hijau adalah $77 \%$ dan kadar total fenolik pasta gigi katekin teh hijau $41 \%$ telihat pada Tabel 2. Selanjutnya dilakukan uji daya hambat pasta gigi ekstrak teh hijau untuk menguji

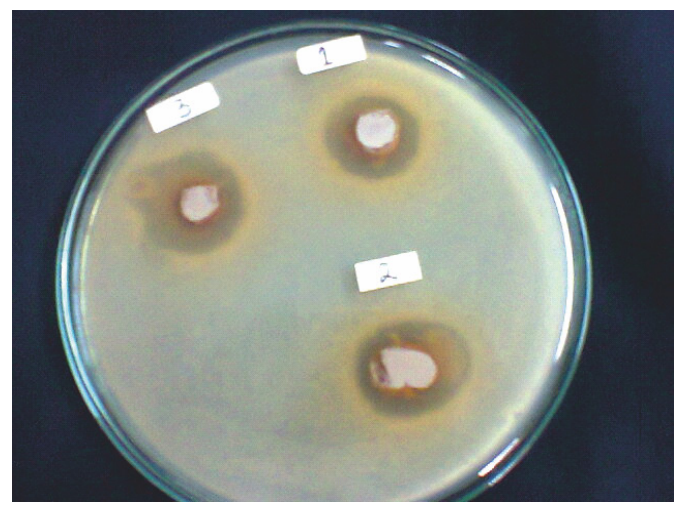

Gambar 3. Lactobacillus acidophilus aktivitas antibakteri melalui pengukuran diameter daerah hambatan. Hasil pengamatan terlihat pada Gambar 3 untuk hambatan bakteri Streptococcus mutans dan Gambar 4 hambatan terhadap bakteri Laktobaccilus acidophilus.

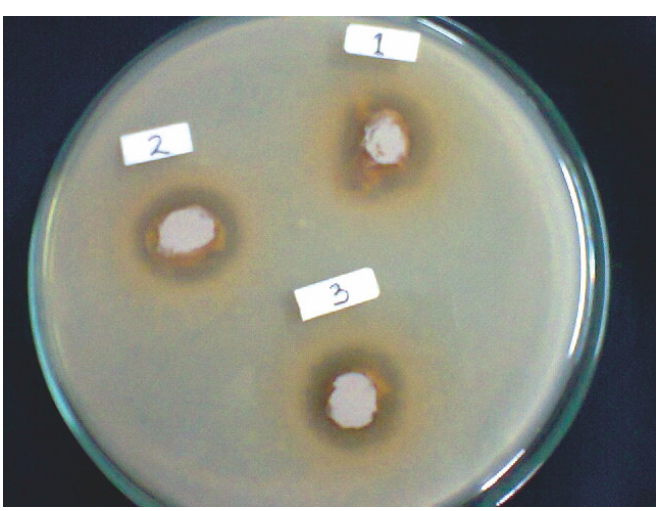

Gambar 4. Streptococcus mutans 
Tabel 3. Diameter daerah hambatan pasta gigi katekin teh hijau terhadap bakteri Streptococcus mutans dan Lactobaccilus acidophilus

\begin{tabular}{ccccc}
\hline No & \multicolumn{4}{c}{ Diameter daerah hambatan (mm) } \\
\hline \multirow{2}{*}{ S. mutans } & 17,76 & 17,38 & 16,48 & 17,21 \\
\hline L.acidophilus & 17,86 & 19,08 & 21,77 & 19,57 \\
\hline
\end{tabular}

Hasil rata-rata diameter hambatan pasta gigi katekin teh hijau, terhadap bakteri Streptoccocus mutans $17,21 \mathrm{~mm}$ dan hasil rata-rata diameter hambatan pasta gigi katekin teh hijau terhadap bakteri Lactobaccilus accidophilus 19,57 mm (Tabel $3)$.

\section{PEMBAHASAN}

Uji konsentrasi hambat minimal (KHM) ekstrak katekin teh hijau pada bakteri Streptococcus mutans dan bakteri Lactobaccillus acidophilus didapatkan hasil yang sama. Namun setelah berbentuk pasta gigi terlihat perbedaan terhadap hambatan kedua bakteri tersebut, walaupun perbedaan ini tidak signifikan, yaitu pada Streptoccocus mutans rerata diameter hambatannya sebesar 17,21 $\mathrm{mm}$ dan Lactobaccilus achidophilus rerata diameter hambatannya sebesar 19,57 $\mathrm{mm}$ sehingga perbedaan diameternya sebesar 2,36 $\mathrm{mm}$. Hasil ini memperlihatkan bahwa rerata diameter hambatan pasta gigi katekin teh hijau pada bakteri Lactobaccilus achidophilus lebih tinggi dibandingkan dengan bakteri Streptococcus mutans. Pernyataan ini dapat dipertanggung jawabkan sebab kandungan flafonoid $77 \%$ dan fenoliknya $41 \%$ dengan perlakuan yang sama pada masing-masing bakteri. Sedangkan pada penelitian yang dilakukan oleh Arifa Tahir dan Rabia Moeen, menyatakan semakin besar konsentrasi ekstrak teh hijau maka semakin tinggi diameter hambatannya terhadap bakteri Streptoccocus mutans dan Lactobaccilus achidophilus. ${ }^{15.16}$

Pasta gigi katekin teh hijau terbukti sangat efektifuntukmenghambataktivitas bakterikariogenik yaitu Streptoccocus mutans $(17,21 \mathrm{~mm})$ dan Lactobaccilus achidophilus (19,57 mm). Komponen bioaktif dari teh hijau mampu mempengaruhi proses terjadinya karies gigi dengan menghambat proliferasi, produksi asam, metabolisme, dan aktivitas enzim glukosiltransferase (GTF) dari Streptococcus mutans dan plak. Produk alami telah digunakan selama ribuan tahun sebagai obat rakyat untuk beberapa tujuan. Karena sebagian besar penyakit oral disebabkan oleh infeksi bakteri dan telah dilaporkan bahwa tanaman obat sangat efektif sebagai antibakteri yang cukup besar terhadap berbagai mikroorganisme termasuk bakteri penyebab gigi karies (Anna et al., 2000). Karies gigi merupakan salah satu penyakit yang umumnya diderita manusia, telah terbukti bahwa komponen bioaktif teh hijau mampu mempengaruhi proses pembentukan karies pada beberapa tahapan yang berbeda: yaitu dapat menghambat proliferasi agen streptokokus, mengganggu proses adhesi pada enamel gigi atau bertindak sebagai inhibitor dari glucosyl transferase dan amilase (Peter et al., 2005).5,7,9,11,12

\section{KESIMPULAN}

Pasta gigi katekin teh hijau telah berhasil dibuat dan terbukti efektif menghambat aktivitas bakteri Streptococcus mutans dan bakteri Lactobaccilus acidophilus. Daya hambat pasta gigi katekin teh hijau lebih tinggi pada aktifitas bakteri Lactobaccilus acidophilus dibandingkan pada bakteri Streptococcus mutans.

\section{DAFTAR PUSTAKA}

1. Roberson TM, Heymann HO, Swift EJ. Sturdevant's art \& science of operative dentistry $4^{\text {th }}$ ed. Copenhagen: Mosby Company; 2002, p.65. 
2. Tedjosasongko U, Pradopo S, Nuraini P. Perubahan oral flora dan sensitifitas karies gigi anak setelah pengulasan fluoride secara topikal. J. Penelit. Med. Eksakta. 2008; 7(1): 9.

3. Darwita RR, Novrinda $H$, Budiharto, Pratiwi PD, Amalia R, Asri SR. Efektivitas Program Sikat Gigi Bersama terhadap Risiko Karies Gigi pada Murid Sekolah Dasar. Journal Indonesian Medical Association. 2011; 61(5): 204-9.

4. Neeraja R, Anantharaj A, Praveen P, Karthik $V$, Vinitha $M$. The effect of povidone-iodine and chlorhexidine mouth rinses on plaque Streptococcus mutans in 6-12 year-old school children. $J$ Indian Soc Period Pedod Prevent Dent. 2008: 14-8.

5. Kocak MM, Ozcan S, Kocak S, Topuz O, Erten $\mathrm{H}$. Comparison of the efficacy of three different mouthrinse solutions in decreasing the level of Streptococcus mutans in saliva. Eur J Dent. 2009; 3: 57-61.

6. Gupta N, Bhat M. Comparative evaluation of 0.2 percent chlorhexidine and magnetized water as a mouth rinse on Streptococcus mutans in children. International Journal of Clinical Pediatric Dentistry. 2011; 4(3): 190-4.

7. Tehrani $\mathrm{MH}$, Asghari G, Hajiahmadi M. Comparing Streptococcus mutans and Lactobacillus colony count changes following green tea mouth rinse or sodium fluoride mouth rinse use in children. Dental Research Journal. 2011; 8(5): 58-63.

8. Arab A, Maroofian A, Golestani S, Shafaee $\mathrm{H}$, Sohrabi K, Forouzanfar A. Review of the therapeutic effects of Camellia sinensis (green tea) on oral and periodontal health. Journal of Medicinal Plants Research. 2011; 5(23): 546469.
9. Tehrani MH, Asghari G, Hajiahmadi M. Comparing Streptococcus mutans and Lactobacillus colony count changes following green tea mouth rinse or sodium fluoride mouth rinse use in children. Dental Research Journal. 2011; 8(5): 58-63.

10. Wijaya D, Samad R. Daya hambat teh hitam, teh hijau, dan teh golong terhadap pertumbuhan Streptococcus mutans. Journal of Indonesia Dental Association. 2005: 82-7.

11. Cabrera C, Artacho R, Gimenez R. Beneficial effects of green tea. J Am Coll Nutr. 2006; 25(2): 79-99.

12. Hilda Butler. Poucher's Perfumes, cosmetic and soap. Kluwer Academic Publisher, London, 2011; 223-246.

13. Tahir A dan Moein R, Comparison of antibacterial activity of water andethanol extracts of Camellia sinensis (L.) Kuntze against dental caries and detection of antibacterial. Journal of Medicinal Plants Research Vol. 5(18), 2011. 4504-4510.

14. Nagappan N, John J. Antimicrobial efficacy of herbal and chlorhexidine mouth rinse. Journal of Dental and Medical Sciences. 2012; 2(4): 5-10.

15. Jigisha A, Nishant R, Navin K, Pankaj G. Green Tea: A magical herb with miraculous outcomes. International Research Journal of Pharmacy. 2012; 3(5): 139-148.

16. Mahmood T, Akhtar N, Khan BA. The morphology, characteristics, and medicinal properties of Camellia sinensis' tea. Journal of Medicinal Plants Research. 2010; 4(19): 2029. 